Louisiana State University

LSU Digital Commons

$12-1994$

\title{
Comparison of Continuous Records of Near-Bottom Dissolved Oxygen from the Hypoxia Zone along the Louisiana Coast
}

Nancy N. Rabalais

William J. Wiseman

R. Eugene Turner

euturne@lsu.edu

Follow this and additional works at: https://digitalcommons.Isu.edu/oceanography_coastal_pubs

Part of the Oceanography Commons

\section{Recommended Citation}

Rabalais, N. N., Wiseman, W. J., \& Turner, R. (1994). Comparison of Continuous Records of Near-Bottom Dissolved Oxygen from the Hypoxia Zone along the Louisiana Coast. Estuaries, 17(4), 850-861. Retrieved from https://digitalcommons.Isu.edu/oceanography_coastal_pubs/151 


\title{
Comparison of Continuous Records of
}

\section{Near-Bottom Dissolved Oxygen From the}

\section{Hypoxia Zone Along the Louisiana Coast}

\author{
Nancy N. Rabal,als ${ }^{1}$ \\ Louisiana Universities Marine Consortium \\ 8124 Highway 56 \\ Chauvin, Louisiana 70344 \\ William J. Wisemar, JR. \\ Coastal Studies Institute and \\ Department of Oceanography and Coastal Sciences \\ Louisiana State University \\ Baton Ronge, Louisiana 70803 \\ R. Eugene Turner \\ Coastal Ecology Institute and \\ Department of Oceanography and Coastal Sciences \\ Louisiana State University \\ Baton Rouge, Louisiana 70803
}

\begin{abstract}
Oxygen depletion is a seasonally dominant feature of the lower water column on the highly-stratified, riverine-influenced continental shelf of Louisiana. The areal extent of hypoxia (bottom waters $\leq 2 \mathrm{mg} \mathrm{1^{-1 }}$ dissolved oxygen) in mid-summer may encompass up to $9,500 \mathrm{~km}^{2}$, from the Mississippi River delta to the upper Texas coast, with the spatial configuration of the zone varying interannually. We placed two continuously recording oxygen meters (Endeco 1184 ) within $1 \mathrm{~m}$ of the seabed in 20 -m water depth at two locations $77 \mathrm{~km}$ apart where we previousty documented midsummer bottom water hypoxia. The oxygen meters recorded considerably different oxygen conditions for a 4-mo deployment from mid-June through mid-October. At the station off Terrebonne Bay (C6A), bottom waters were severely depleted in dissolved oxygen and often anoxic for most of the record from mid-June through mid-August, and there were no strong diurnal or diel patterns. At the station $77 \mathrm{~km}$ to the east and closer to the Mississippi River delta (WD32E), hypoxia occurred for only $50 \%$ of the record, and there was a strong diurnal pattern in the oxygen time-series data. There was no statistically significant coherence between the oxygen time-series at the two stations. Coherence of the oxygen records with wind records was weak. The dominant coherence identified was between the diurnal peaks in the WD32E oxygen record and the bottom pressure record from a gauge located at the mouth of Terrebonne Bay, suggesting that the dissolved oxygen signal at WD32E was due principally to advection by tidal currents. Although the oxygen timeseries were considerably different, they were consistent with the physical and biological processes that affect hypoxia on the Louisiana shelf. Differences in the time-series were most intimately tied to the topographic cross-shelf gradients in the two locations, that is, station C6A off Terrebonne Bay was in the middle of a broad, gradually sloping shelf and station WD32E in the Mississippi River Delta Bight was in an area with a steeper cross-shelf depth gradient and likely situated near the edge of a hypoxic water mass that was tidally advected across the study site.
\end{abstract}

\section{Introduction}

Oxygen-depleted bottom waters are seasonally dominant features of the Louisiana continental shelf adjacent to the deltas of the Mississippi and Atchafalaya rivers (Rabalais et al. 1991, 1992). In mid-summer, the areal extent of bottom-water hypoxia ( $\leq 2 \mathrm{mg} \mathrm{l}^{-1}$ dissolved oxygen (DO)) may cover up to $9,500 \mathrm{~km}^{2}$, with spatial configuration of the

\footnotetext{
' Corresponding Author.

zone varying interannually. More frequent sampling along a transect on the southeastern shelf and continuous time-series data off Terrebonne Bay document hypoxic bottom waters as early as Fcbruary and as latc as October, with widespread, persistent, and severe hypoxia-anoxia from midMay to mid-September.

The Mississippi River system, which empties onto the northern Gulf of Mexico continental shelf, ranks among the world's top ten rivers in terms of 
freshwater and sediment inputs to the coastal ocean (Milliman and Meade 1983), drains $41 \%$ of the conterminous United States, and contributes over $90 \%$ of the fresh water to the Gulf of Mexico (Dinnel and Wiseman 1986). High flow occurs in March-May. Although river flow is reduced in summer, seasonal wind reversals retain much of the fresh water on the shelf. A productive, stratified system is maintained for the majority of the year (Sklar and Turner 1981; Justic et al. 1993). The vertical distribution of the hypoxic water mass is defined by water-column stratification, which is controlled by riverine freshwater inflow, large-scale circulation, and wind-driven mixing (Rabalais et al. 1991, 1992; Wiseman et al. 1992).

Freshwater discharge from the Mississippi and Atchafalaya rivers rapidly forms the I ouisiana Coastal Current, a highly stratified coastal current that flows, in the mean, westward along the Louisiana coast and southward along the Texas coast. During late spring and summer, however, when winds along the south Texas coast are upwellingfavorable, the flow reverses and flows back toward the north and east (Cochrane and Kelly 1986). In some years the reversal penetrates into Louisiana waters during mid-summer. Stratification in the Louisiana Coastal Current, particularly near the two major freshwater sources, is primarily due to salinity. During winter, temperature is destabilizing; from April until October, it is normally stabilizing. Strong wind events interact with the waters of the coastal current throughout the ycar. Intense wind mixing due to cold air outbreaks and frontal passages is active from as early as late September to as late as June; while local squalls and thunderstorms, as well as tropical storms and hurricanes, are important during the summer months (DiMego et al. 1976). These wind events often result in the complete homogenization of the water-column (Wiseman et al. 1986). At other times, they are not strong enough to fully break down the local stratification, but they result in localized coastal upwclling, which alters the stratification (Dagg 1988).

High biological productivity in the immediate and extended plumes of the Mississippi River (Sklar and Turner 1981; Iohrenz et al. 1990) is mediated by high nutrient inputs and regeneration, and favorable light fields. Subsequent carbon flux (via direct sinking, repackaging, aggregate formation, or advection) is sufficient to deplete the lower water column of oxygen within periods of days to wceks to months (Turner and Allen 1982; Dortch et al. 1994). Once hypoxic water masses have formed, they persist until mixing results from winds and/or thermal cooling, or the advection of oxygenated water during upwelling- or downwell- ing-favorable conditions. The highest net productivity in the adjacent shelf system lags 1 mo after peak river flow; the most deficient bottom water oxygen lags 2 mo behind peak river flow (Justić et al. 1993).

We have documented interannual variability of oxygen depletion over a large geographic region and monthly or bimonthly variability on a limited spatial scale (Rabalais et al. 1991, 1992). Continuous time-series data from more than a single location were not available until the simultaneous deployment of two oxygen meters in 1990 (Rabalais et al. 1993). The second meter was deployed in the Mississippi River Delta Bight $77 \mathrm{~km}$ closer to the outflow of the Mississippi River but in the same water depth as the oxygen meter on a permanent instrument mooring off 'Terrebonne Bay (Fig. 1). Thus, measurements were obtained from two oxygen meters at $20-\mathrm{m}$ water depth in areas of consistent mid-summer hypoxia, and we were able to assess whether the bottom-water oxygen environment was similar in the two areas and to explore the possible forcing mechanisms of variability.

\section{Methods \\ STUDY AREA}

The study area encompassed the Mississippi River Delta Bight downplume of Southwest Pass of the Mississippi River and the area offshore of Terrebonne Bay (Fig. 1). The oxygen meters were located at WD32F $\left(29^{\circ} 07.63^{\prime} \mathrm{N}, 89^{\circ} 41.46^{\prime} \mathrm{W}\right.$; an active oil-production platform) and $66 \mathrm{~A}\left(28^{\circ} 51.44^{\prime} \mathrm{N}\right.$, $90^{\circ} 27.68^{\prime} \mathrm{W}$; an inactive platform). Platform-related effects were evident in scdimentary characteristics (physical and chemical) and benthic community structure but not on water-column structure, including oxygen concentrations (Rabalais et al. 1993).

\section{INSTRUMENTATION AND I HYDROGRAPHY}

Time-series measurements were made using Endeco 1184 pulsed dissolved oxygen sensors sampling at 15 -min intervals. Both instruments were deployed within $1 \mathrm{~m}$ of the seabed in a $20-\mathrm{m}$ water column. Instruments were deployed from midJune through mid-October with a probe replacement midway through each deployment. Predeployment and postdeployment calibration of the pulsed DO sensors (accuracy of $0.2 \mathrm{mg} \mathrm{l}^{-1}$ ) were performed by technicians of Endeco, Inc. according to specifications of the instrument (Endeco, Inc. 1988). An antifouling wax was applied to the center of the DO sensor membrane, and both instruments were resistant to the effects of bio-fouling. With the exception of one deployment period at $\mathrm{C} 6 \mathrm{~A}(6 / 15 / 90-7 / 20 / 90)$, there were no indi- 


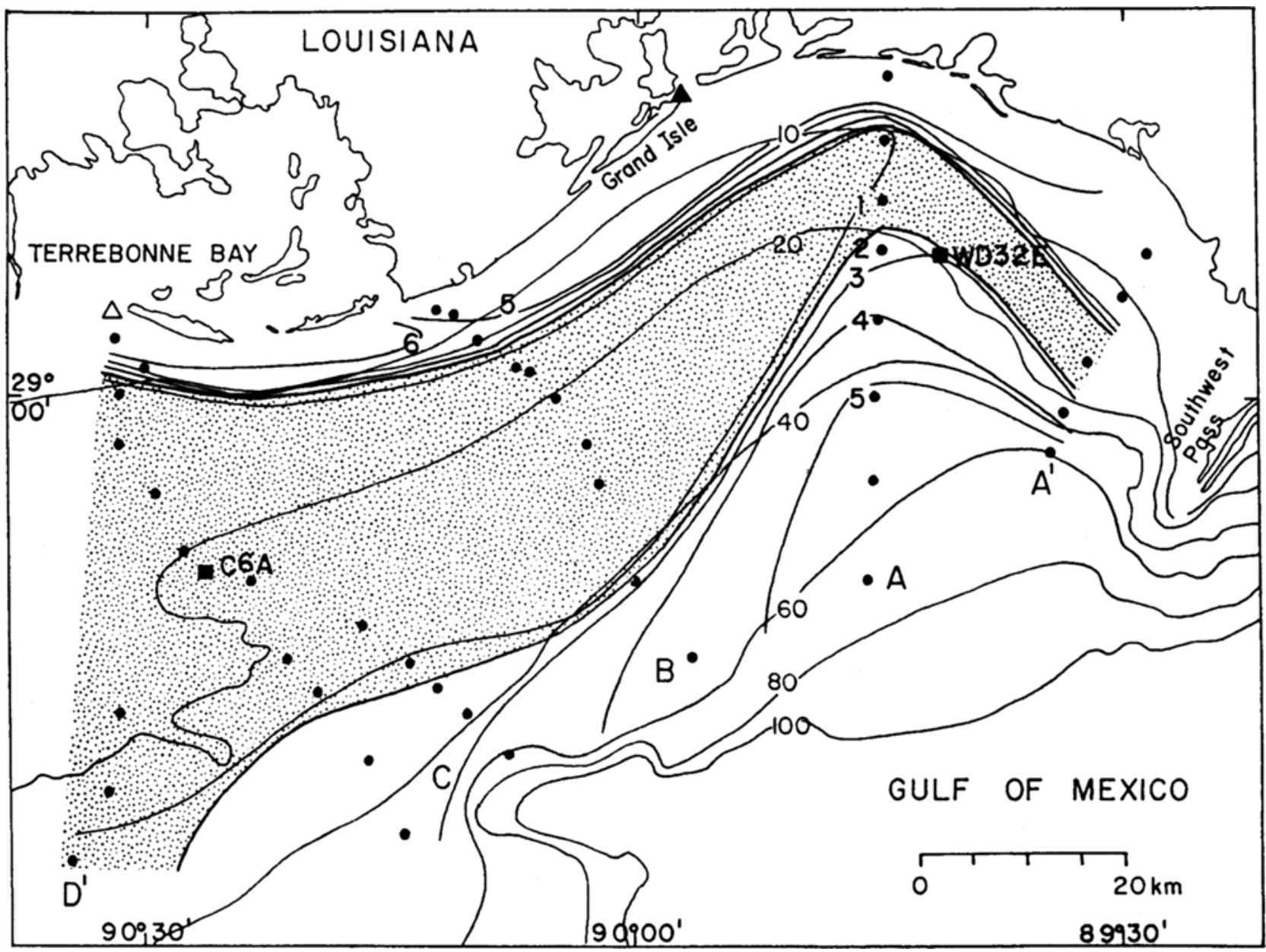

Fig. 1. Map of study area with location of hydrographic survey stations along transects $\mathrm{A}^{\prime}$ through $\mathrm{D}^{\prime}$, oxygen meter locations (closed squares), pressure gauge location in Cat Island Pass at the mouth of Terrebonne Bay (open triangle), and C-MAN wind gauge location at Grand Isle (closed triangle). Stippled area represents spatial extent of near-bottom water hypoxia (DO $\leq 2 \mathrm{mg} \mathrm{l}{ }^{1}$ ) during mid-July to late-July 1990 . Isobaths in $10 \mathrm{~m}$ to $100 \mathrm{~m}$; oxygen isopleths in $1 \mathrm{mg} \mathrm{l}^{-1}$ to $6 \mathrm{mg} \mathrm{l}^{-1}$.

cations from the condition of any DO probes that hydrogen-sulfide poisoning had occurred. Postcalibration of the discolored probe (C6A), periodic corroboration of DO data with a Hydrolab Surveyor II (accuracy of $0.2 \mathrm{mg} \mathrm{l}^{-1}$ ), and collection of similar data following probe exchange, indicated that the values for the first part of the deployment at C6A were accurate and usable.

Bottle samples for detcrmination of DO by Winkler titration (Parsons et al. 1984) were taken periodically during deployment of the instruments. Supplemental DO data were obtained during frequent hydrographic surveys of the study areas using a Ilydrolab Surveyor II or a SeaBird CTD/DO (accuracy of $0.1 \mathrm{ml} \mathrm{l}^{-1}$ ) system. Numerous discrete samples and hydrographic profiles indicated that oxygen meters were, for the most part, representative of the near-bottom DO conditions at the point of instrument placement and within a $1,000-\mathrm{m}$ radius of the instrument. Postdeployment corrections to the Endeco 1184 DO concentrations were made if Winkler titrations and Hydrolab measurements showed a consistent offset for any deployment period, as was the case for a portion of the WD32E record.

The DO concentration below which waters were considered "hypoxic" was designated as $2 \mathrm{mg} 1$ ', based on the absence of demersal finfish and crustaceans in trawl catches when dissolved oxygen falls below that level (Pavela et al. 1983; Leming and Stuntz 1984; Renaud 1986; N. N. Rabalais personal observation).

\section{Bottom Pressl:Re AND Winds}

Time-series analyses were conducted to compare dissolved oxygen with bottom pressure records collected from within the Cat Island Pass entrance to Terrebonne Bay (Fig. 1). Tide gauge data for 
Grand Isle were not available, but prior studies (Murray 1976) suggest that the tide does not vary significantly between Grand Isle and the entrances to Terrebonne Bay. A ScaBird SBE 26 pressure gauge, set to sample at 15 -min intervals, was deployed and serviced at regular intervals. The accuracy and resolution of the instrument are 46.5 $\mathrm{Pa}$ and $1.24 \mathrm{~Pa}$, respectively. No effort was made to correct pressure gauge data for atmospheric pressure to recover sea-level records. Our primary concern was with the tidal periods where the bottom pressure signal is significantly greater than the atmospheric pressure signal. Also, bottom pressure, which includes atmospheric pressure and baroclinic signals, is a more fundamental measurement relating to bottom water movement than is water level. Wind data were obtained from the C-MAN station at Grand Isle (Fig. 1). The winds were rotated $45^{\circ}$ to be more nearly longshore near the instrument deployment at C6A.

\section{Data ANalyses}

Hourly data were entered into spreadsheets for calculations of frequency of records and duration of events at various DO levels, and determination of daily DO minima, maxima, ranges, and averages. The 4-mo record for DO time-series were divided into cqual monthly intervals for each station for calculation of monthly values. Spectra for the entire 4-mo DO time-serics were estimated to determine the energy containing scales of various observables. The periodogram was calculated from the discrete Fourier transform (Cooley and Tukey 1965). The power spectrum was then estimated by smoothing the periodogram with an 11-point triangular running filter giving four equivalent degrees of freedom for the spectrum estimates. (A curve was then smoothed through these estimates to provide spectra as in Fig. 5 used later in this paper.) Coherence squared estimates between time-series were estimated from the discrete Fourier transforms. These were estimated by averaging across five adjacent bands giving ten degrees of freedom to each estimate.

\section{Results and Discussion \\ OXYGen Time-Series}

Continuous time-series data for near-bottom dissolved oxygen concentrations at the two locations are shown in Fig. 2. The near-bottom dissolved oxygen environments were usually very different between the two stations.

Extended periods of hypoxic and anoxic nearbottom waters were recorded at station $\mathrm{C} 6 \mathrm{~A}$ off Terrebonne Bay (Fig. 1), particularly in the first 2 mo of the record, that is, mid-June through midAugust (Fig. 2). DO concentrations fell below $2 \mathrm{mg}$
$1^{-1}$ for $80 \%$ of the total record and below $1 \mathrm{mg}^{-1}$ for $71 \%$ of the total record, and were anoxic for $60 \%$ of the total record (derived from Table 1). The DO was almost always anoxic (or sometimes hypoxic) until August 19. The frequency of normoxic water $\left(D O>2 \mathrm{mg} \mathrm{l}^{-1}\right)$ increased dramatically in the third and fourth months of the record (Table 1) with two extended periods of reoxygenation in mid-August to early September and again from early to mid-October. After October 2, the DO was above $2 \mathrm{mg} \mathrm{l}^{-1}$ for the remainder of the record.

The oxygen time-series in the Mississippi River Delta Bight at station WD32F, was much different with periodic fluctuations above and below $2 \mathrm{mg}$ $1^{-1}$ DO (Fig. 2). Hypoxia occurred overall for $50 \%$ of the total record, and more frequently in the first and third months (derived from Table 1 ). The duration of hypoxic events was longer in the first month of the record than in the subsequent three months.

Hypoxic events, at all levels considered $(\mathrm{DO}=$ $0 \mathrm{mg} \mathrm{l}^{-1}, 0 \mathrm{mg} \mathrm{l}^{1}<\mathrm{DO} \leq 1 \mathrm{mg} \mathrm{l}^{-1}, 0 \mathrm{mg} \mathrm{l}^{-1}<$ $\mathrm{DO} \leq 2 \mathrm{mg} \mathrm{l}^{1}$ ) were longer in duration at station C6A than at WD32E (Table 1). For the first 2 mo of the record, the daily DO minima and DO maxima were significantly lower at station C6A than at WD32E (Table 1). The daily DO minima and maxima were lower at C6A than WD32E in the second 2 mo of the record but not always significantly. The daily range in $D O$ values was significantly greater at station WD32F than at C6A for the first 3 mo of the record. The daily DO average was lower at station C6A than at WD32F for the first 2 mo of the record.

\section{HYDROGRAPHY}

In addition to the obvious differences in the DO time-series for the two stations, the water-column structure at mid-month intervals through the period of instrument deployments also differed. Dissolved oxygen minima were observed in the lower water column below a strong thermocline or halocline for all mid-month surveys (four shown in Fig. 3). All station data from the WD32E site during the course of the summer, five profiles, indicated a mid-depth oxygen minimum (three shown in Fig. 3 ). Some profiles exhibited more than one such minimum and others showed a near-bottom oxygen minimum. From mid-Junc through mid-September, upper water-column tempcratures were cooler at station WD32E than at C6A; WD32E is considerably closer to the effluent of the Mississippi River than C6A (Fig. 1). For the same time period, upper water-column salinities were also lower at station WD32E than at C6A. Profiles for midOctober for both stations showed a relaxation in 

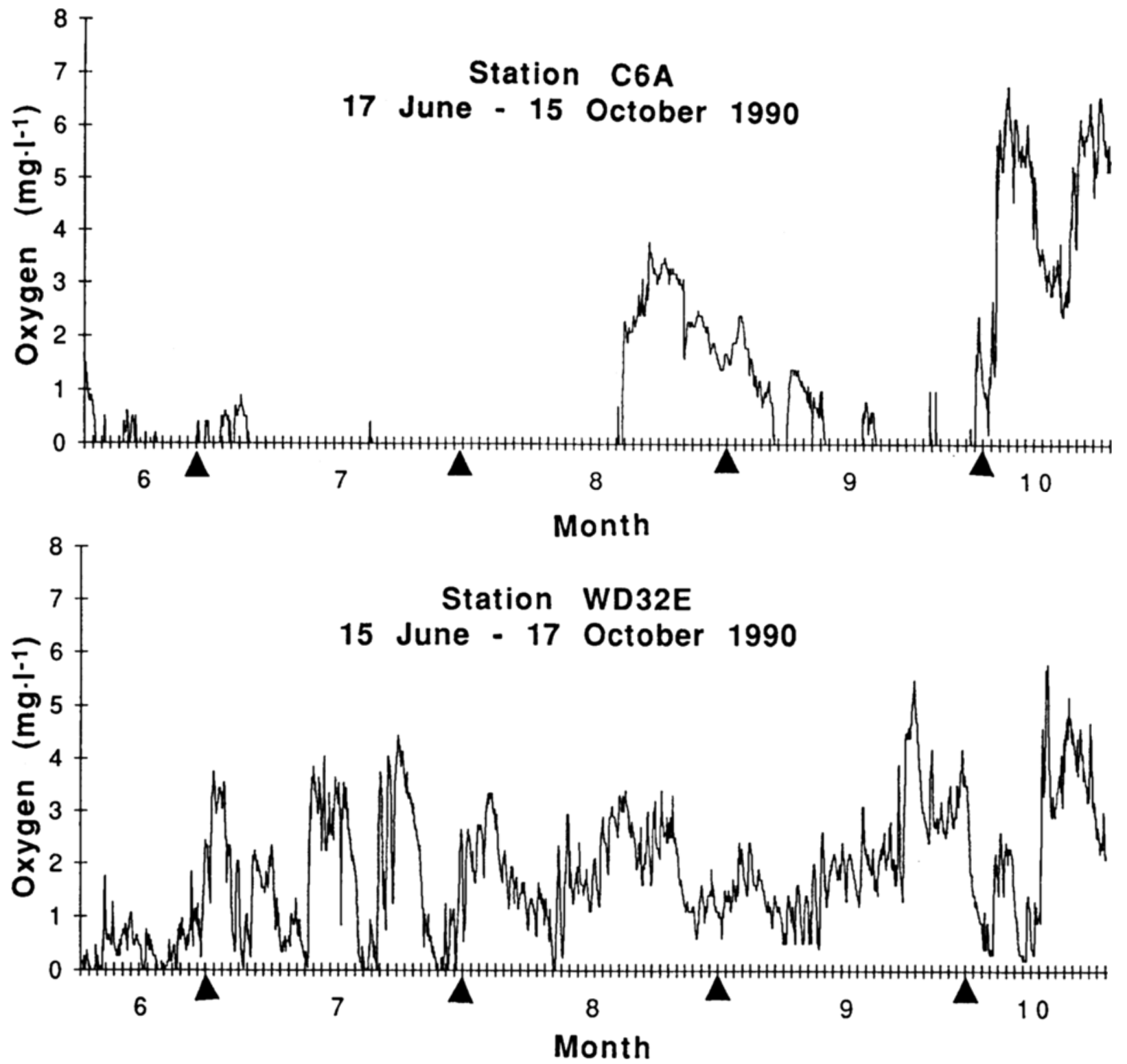

Fig. 2. 'Iïme-series plots of near-bottom dissolved oxygen concentration (mg $l^{1}$ in 1 -h intervals) at stations C6A and WD32E. (closed triangles indicate beginning of month indicated).

the strength of the thermocline as a result of seasonal cooling (Fig. 3).

We created oxygen versus salinity, temperature versus salinity, and depth versus salinity plots for all mid-month profiles at station WD32E (Fig. 4). Where well-developed mid-depth oxygen minima occur (e.g., Fig. 4, June 15, 1990), they are associated with strong haloclines in the depth versus salinity plots and temperature versus salinity plots which cross the lines of constant density at large angles. Water disperses preferentially along isentropic surfaces rather than across them (Montgomery 1938). This suggested that the mid-depth min- ima were advecting or diffusing offshore along pycnoclines from near-bottom source regions closer to shore. The pycnoclines were not associated with the same density surface throughout the summer. In particular, waters in June were colder and denser at a given salinity than they were in July, August, or September. This is consistent with previous observations of the seasonal variation of water mass properties in the region (Wiseman et al. 1982). It is also consistent with the distribution of hypoxic bottom waters found inshore of WD32E in July 1990 (Fig. 1) and during other mid-summer synoptic surveys (see below). 
TABI.F. 1. Comparison of time-series of dissolved oxygen (DO) measurements ( $m l^{1}$ ) from two locations, station (C6A and station WD32E, in the zone of hypoxia on the Iouisiana shelf.

\begin{tabular}{|c|c|c|c|c|c|c|c|c|}
\hline $\begin{array}{l}\text { Station: } \\
\text { Period: }\end{array}$ & $\begin{array}{c}\text { C6A } \\
\text { lune } 15 \\
199(- \text { July } \\
14,1990\end{array}$ & $\begin{array}{c}\text { C6A } \\
\text { July 15, } \\
\text { 1940,-August } \\
14,1996\end{array}$ & $\begin{array}{c}\text { C6A } \\
\text { August 15, } \\
1990-5 \text { eptember } \\
15,1990\end{array}$ & $\begin{array}{c}\text { CGA } \\
\text { Seprember } 16, \\
1990-\text { October } \\
15,1990\end{array}$ & $\begin{array}{l}\text { WD:32 } \\
\text { June } 15, \\
1996 \text { - July } \\
14,1390\end{array}$ & $\begin{array}{c}\text { WD3:F } \\
\text { July 15. } \\
\text { 1990-Auguist 14 } \\
\text { 1990 }\end{array}$ & $\begin{array}{c}\text { WID32E } \\
\text { August 15, } \\
1990-\text { September } \\
15,090\end{array}$ & $\begin{array}{l}\text { WD325. } \\
\text { September } 16, \\
1190-\text { October } \\
16,1990\end{array}$ \\
\hline \multicolumn{9}{|c|}{ Frequency of Events } \\
\hline $\mathrm{DO}=0$ & $71 \%$ & $99 \%$ & $30 \%$ & $42 \%$ & $1 \%$ & $0 \%$ & $0 \%$ & $0 \%$ \\
\hline $0<D O \leq 1$ & $22 \%$ & $1 \%$ & $14 \%$ & $8 \%$ & $33 \%$ & $6 \%$ & $13 \%$ & $13 \%$ \\
\hline $1<\mathrm{DO}<2$ & $6 \%$ & $0 \%$ & $25 \%$ & $5 \%$ & $33 \%$ & $24 \%$ & $55 \%$ & $21 \%$ \\
\hline $2<\mathrm{DO}$ & $1 \%$ & $0 \%$ & $32 \%$ & $45 \%$ & $33 \%$ & $70 \%$ & $32 \%$ & $65 \%$ \\
\hline \multicolumn{9}{|c|}{ Duration of Fvents: $\bar{x} h+S E(n)$} \\
\hline $\mathrm{DO}-0$ & $\begin{array}{c}29.8 \pm 12.5 \\
(17)\end{array}$ & $245.0 \underset{(4)}{ \pm} 180.9$ & $57.5 \pm 20.5$ & $62.0 \pm \frac{(5)}{(5)} 27.0$ & $\begin{array}{c}3.0 \\
(1)\end{array}$ & $\begin{array}{l}N / A \\
(0)\end{array}$ & $\begin{array}{l}\text { N/A } \\
(0)\end{array}$ & $\begin{array}{c}N / A \\
(0)\end{array}$ \\
\hline $0<\mathrm{DO} \leq 1$ & $222.7 \pm 214.2$ & $\begin{array}{l}744 \\
\text { (1) }\end{array}$ & $42.0 \pm 19.0$ & $184.5 \pm \frac{ \pm}{(2)} 169.5$ & $\begin{array}{c}14.2 \pm 5.7 \\
(17)\end{array}$ & $\begin{array}{c}4.5 \pm 1.5 \\
(10)\end{array}$ & $\begin{array}{c}26.7 \pm 12.5 \\
(20)\end{array}$ & $14.7 \underset{(7)}{ \pm} 5.8$ \\
\hline $0<\mathrm{DO} \leq 2$ & $236.0 \pm 210.7$ & $\begin{array}{l}744 \\
(1)\end{array}$ & $129.2+67.5$ & $134.7 \underset{(3)}{ \pm} 113.4$ & $\begin{array}{c}43.0+21.4 \\
(11)\end{array}$ & $\begin{array}{c}14.8 \pm 5.1 \\
(15)\end{array}$ & $\begin{array}{c}8.1 \pm 3.3 \\
(10)\end{array}$ & $\begin{array}{c}16.5 \pm 7.7 \\
(17)\end{array}$ \\
\hline \multicolumn{9}{|c|}{ Daily DO Concentration: $\times \mathrm{mg}^{-1} \pm \mathrm{SE}(\mathrm{n}:=30$ or 31$)$} \\
\hline Minimum & $0.1 \pm 0.0$ & $0.0 \pm 0.0$ & $1.1 \pm 0.2$ & $1.7 \pm 0.4$ & $1.1 \pm 0.2^{*}$ & $1.8 \pm 0.2 \%$ & $1.3 \pm 0.1$ & $2.0 \pm 0.2$ \\
\hline Maximum & $0.5+0.2$ & $0.2 \pm 0.0$ & $1.7 \pm 0.2$ & $2.7 \pm 0.5$ & $2.3 \pm 0.2^{*}$ & $3.4 \pm 0.2 *$ & $2.2 \pm 0.1^{*}$ & $3.3 \pm 0.2$ \\
\hline Range & $0.4 \pm 0.2$ & $0.2 \pm 0.0$ & $0.5 \pm 0.1$ & $1.0 \pm 0.2$ & $1.2 \pm 0.1^{*}$ & $1.5 \pm 0.2^{*}$ & $0.9 \pm 0.1^{*}$ & $1.4 \pm 0.1$ \\
\hline Aveiage & $0.2 \pm 0.1$ & $0.0 \pm 0.0$ & $1.4 \pm 0.2$ & $2.2+0.4$ & $1.8 \pm 0.2^{*}$ & $2.7 \pm 0.2^{*}$ & $1.7 \pm 0.1$ & $2.6 \pm 0.2$ \\
\hline
\end{tabular}

* Significantly different from paired monthly mean at station C6. $p<0.05$, paired t-test.

\section{SPECTRAI, AND COHERENCF. ANALYSHS}

Spectra of the continuous 4-mo dissolved oxygen records from stations $\mathrm{C} 6 \mathrm{\Lambda}$ and WD32E are shown in Fig. 5. While no obviously significant peaks were present in the spectrum for C6A, a significant peak appeared in the record from WD32E in a band near the diurnal frequency. While suggested in Fig. 5 , the periodogram (not shown) clearly showed that the strongest peaks were in the bands containing the $\mathrm{K}_{1}$ (period $=23.9 \mathrm{~h}$ ) and the $\mathrm{O}_{1}$ (period $=25.8 \mathrm{~h}$ ) tides. Given the length of the available record, it was not possible to separate the $K_{1}$ signal from the 24-h period due to solar insolation. Thus, the signal in this band could be duc to advection by the $\mathrm{K}_{1}$ tidal currents or to phytoplankton activity in response to the day-night cycle of insolation. The fact that the $O_{1}$ dissolved oxygen signal at WD32F was slightly higher than the $\mathrm{K}_{1}$ signal, as observed in the bottom pressure record from Cat Island Pass (see Fig. 5), suggested that the dissolved oxygen signal was due principally to advertion by tidal currents. 'The lowest frequencies, that is, processes with periods longer than $4 \mathrm{~d}$, were the most energetic at both stations. These processes tend to be associated with weather-driven events such as wind-driven mixing, upwelling, and downwelling.

The dissolved oxygen records were not coherent with each other at the $95 \%$ significance level. They were also not coherent with coastal bottom pressure or surface wind. At the $80 \%$ significance level, however, there were isolated bands of coherence. In particular, the dissolved oxygen record from sta- tion WD32E was coherent with the coastal bottom pressure in the diurnal band. There were also other isolated bands of coherence, including a narrow band near semidiurnal frequencies. Coherence of the DO record with the winds was not particularly strong, although narrow isolated bands of coherence existed in both records. Both oxygen records appeared coherent with winds in the 3-d and the 15-d bands.

Past efforts to seek statistically significant coherence between bottom current records and bottom dissolved oxygen at $\mathrm{C} 6 \AA$ have proven futile. Seasonal and shorter scale variations in current structure appear to be strongly influenced by a variety of processes. The diurnal tidal signals are often confounded with inertial oscillations (Daddio et al. 1978) and internal tides (Science Applications International Corporation 1989). The former are most important during the energetic winter season and the latter during the stratified summer season. Furthermore, the alongshore coherence of crossshelf currents along the I ouisiana shelf appears to have extremely short spatial scales (F. J. Kelly personal communication). We have analyzed two records of near-bottom currents in a diurnal band (23-h to 26-h periods), which included the $\mathrm{K}_{1}, \mathrm{O}_{1}$, and inertial periods, and a semidiurnal band (12-h to 13 -h periods). The filtered records showed the expected strong temporal variability in envelope amplitude. Descriptive statistics are presented in Table 2. Over $12 \mathrm{~h}$ of onshore flow, an rms speed of $1 \mathrm{~cm} \mathrm{~s}{ }^{1}$ would displace a water parcel approximately $0.4 \mathrm{~km}$. When added to the displacement 
STATION CGA
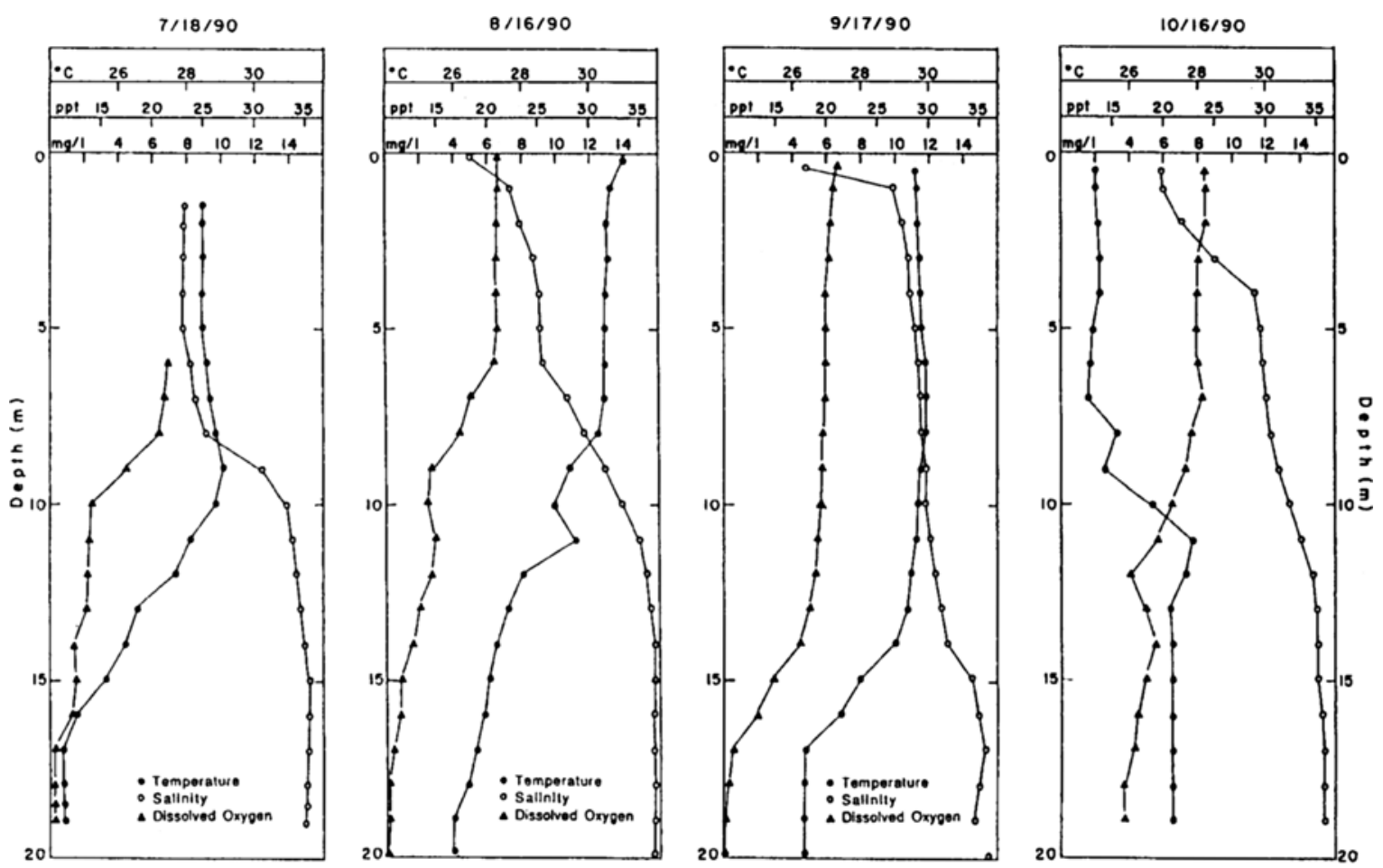

\section{STATION WD32E}
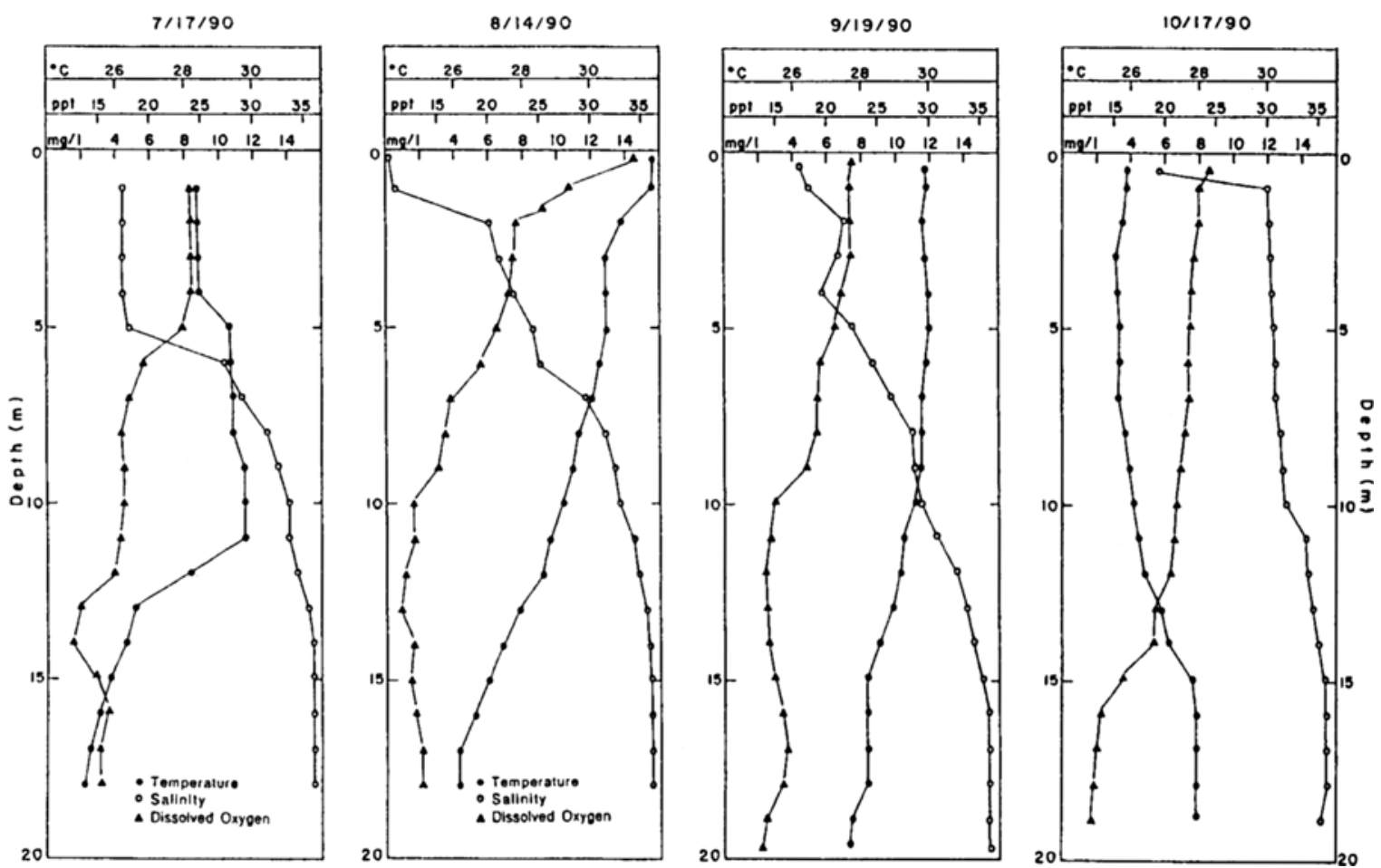

Fig. 3. Water-column vertical profiles of salinity $(\% \mathrm{c})$, temperature $\left({ }^{\circ} \mathrm{C}\right)$, and dissolved oxygen $\left(\mathrm{mg} \mathrm{l}^{-1}\right)$ for stations $\mathrm{C} 6 \mathrm{~A}$ and WD $32 \mathrm{E}$ for dates indicated. 

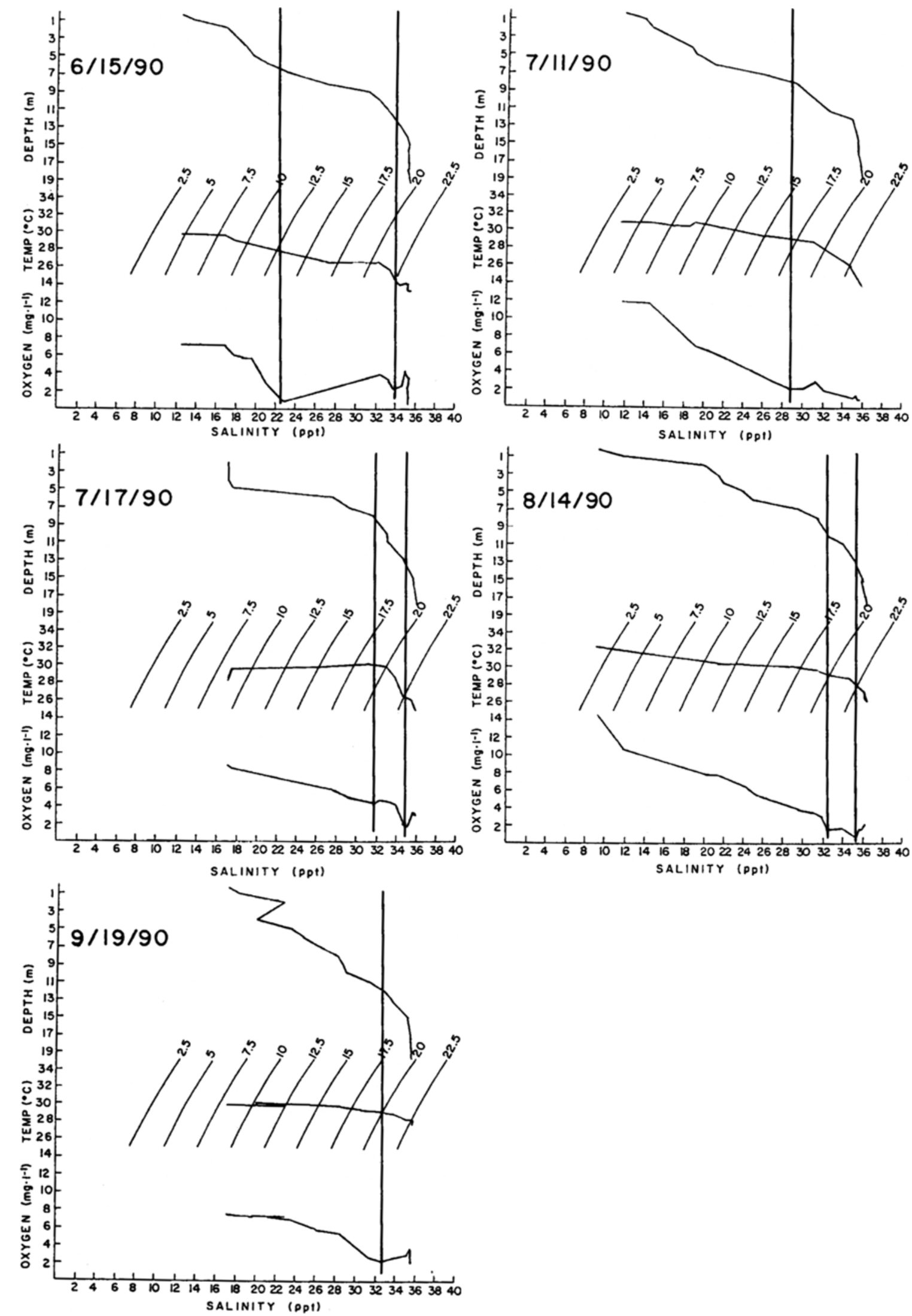

Fig. 4. Plots of oxygen (mg $\left.\left.\right|^{1}\right)$ versus salinity $(\% \circ)$, temperature: $\left({ }^{\circ} \mathrm{C}\right)$ versus salinity $(\% o)$, and depth (m) versus salinity $\left(\%, c^{2}\right)$ with constant density (sigma-t) curves superimposed for dates indicated at station WD32E. Vertical lines through each plot idertify oxygen minima and related temperature and salinity features. 

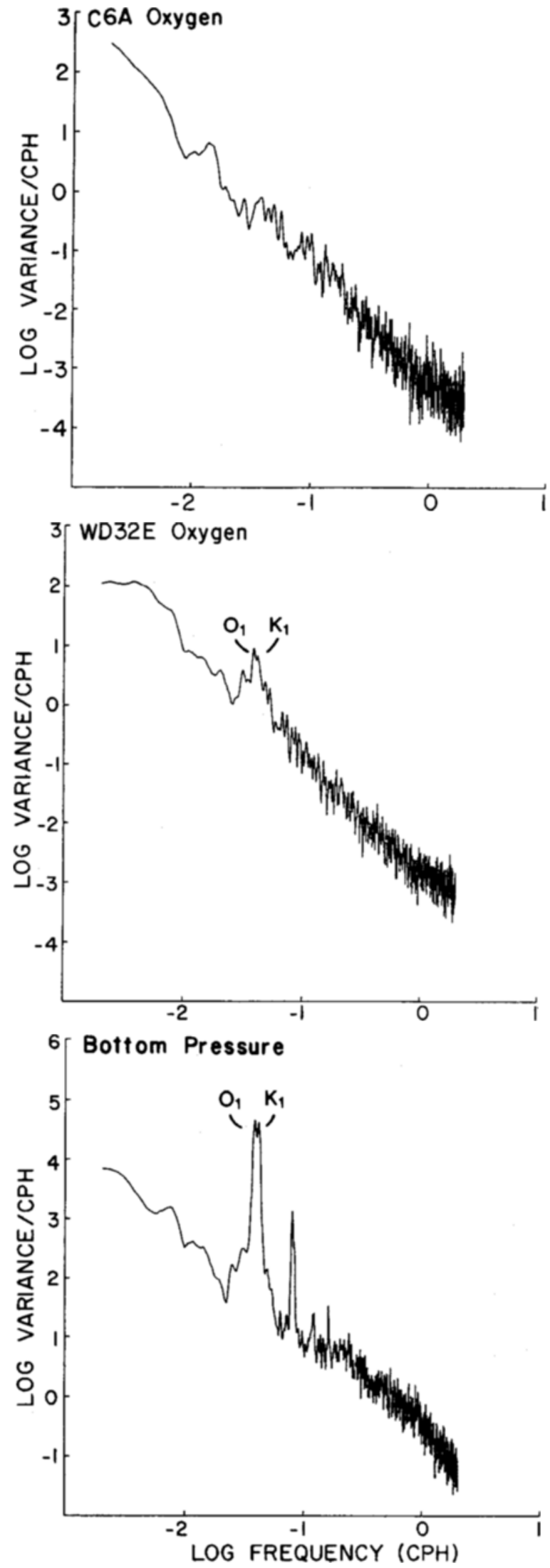

TABLE 2. Descriptive statistics for tidal band, near-bottom currents at station C6A.

\begin{tabular}{|c|c|c|c|c|c|c|c|}
\hline Yicar & $\begin{array}{c}\text { Dorraion } \\
\text { (d) }\end{array}$ & Biand' & Componen & $\begin{array}{c}\text { Speeds } \\
\left(\mathrm{cm} \mathrm{s}^{-1}\right)\end{array}$ & )$_{(\text {maximim }}^{\text {Max }}$ & $\begin{array}{l}\text { Minjomim } \\
\left.(\mathrm{cms})^{\prime}\right)\end{array}$ & $\theta^{s}$ \\
\hline 1989 & 272 & D & East & 1.52 & 5.91 & -5.91 & \\
\hline 1989 & 272 & D & North & 1.47 & 5.04 & -5.02 & \\
\hline 1989 & 272 & D & & & & & $7.5^{\circ}$ \\
\hline 1989 & 272 & $\mathrm{~S}$ & East & 1.26 & 4.71 & -4.72 & \\
\hline 1989 & 272 & $\mathrm{~S}$ & North & 0.99 & 4.57 & -4.57 & \\
\hline 1989 & 272 & $\mathrm{~s}$ & & & & & $-33.5^{\circ}$ \\
\hline 1990 & 211 & D & East & 1.00 & 3.56 & -3.56 & \\
\hline 1990 & 211 & D & North & 1.10 & 3.71 & -3.71 & \\
\hline 1990 & 211 & D & & & & & $50.2^{\circ}$ \\
\hline 1990 & 211 & $\mathrm{~S}$ & East & 1.25 & 3.45 & -3.45 & \\
\hline 1990 & 211 & $\mathrm{~S}$ & North & 0.71 & 2.40 & -2.39 & \\
\hline 1990 & 211 & $\mathrm{~S}$ & & & & & $-21.0^{\circ}$ \\
\hline
\end{tabular}

${ }^{\mathrm{a}} \mathrm{D}$ indicates the diurnal band and $\mathrm{S}$ indicates the semidiurnal.

" $\theta$ is the orientation of the principal axis of the variance ellipse, measured positive counterclockwise from east.

associated with a semidiurnal flow of $1 \mathrm{~cm} \mathrm{~s}$ specd over $6 \mathrm{~h}$, an additional $0.2 \mathrm{~km}$ displacement is to be anticipated. Maximum displacements of roughly $3 \mathrm{~km}$ might be expected due to diurnal and semidiurnal currents (including inertial currents) during extreme events.

The distribution of near-bottom oxygen gradients and extent of mid-summer hypoxia on the southeastern Louisiana shelf are detailed in Fig. 1. The extent of hypoxia near WD32F in 1990 was constricted to a narrow depth range between the birdfoot delta and Grand Isle. The interface of normoxic-hypoxic waters is often near stations $\Lambda 3$ and $\mathrm{A4}$, as it was in 1990, with similar distributions for 1987, 1989, and 1991 (Rabalais et al. 1992, unpublished data). Based on the mid-summer synoptic surveys, it appears that there is more variability in the configuration of the hypoxic area within the Mississippi River Delta Bight than in the arca off 'Terrebonne Bay. Stronger bathymetric gradients nearer the delta (Fig. 1) imply that short cross-gradient excursions may move oxygenated water across the measurement area. Comparison of oxygen gradients and bathymetric contours near WD32E (transect $\mathrm{A}$ for mid-summer 1990) indicatcd that a $1 \mathrm{mg} \mathrm{l}^{-1}$ difference in oxygen concentration could occur within $0.9 \mathrm{~km}$ to $2 \mathrm{~km}$ of the oxygen meter. This is within the calculated distance

$\leftarrow$

Fig. 5. Smoothed periodograms of dissolved oxygen timeseries at C6A (upper panel), dissolved oxygen time-series at WI32E (middle panel), and bottom pressure at mouth of Terrebonne Bay (lower panel). The smoothing was done with a symmetric, 11 -point triangular filter and the results multiplied by a constant factor so that the units of the resultant plots represent estimates of energy spectra. $\mathrm{O}_{1}$ and $\mathrm{K}_{1}$ peaks as indicated. 


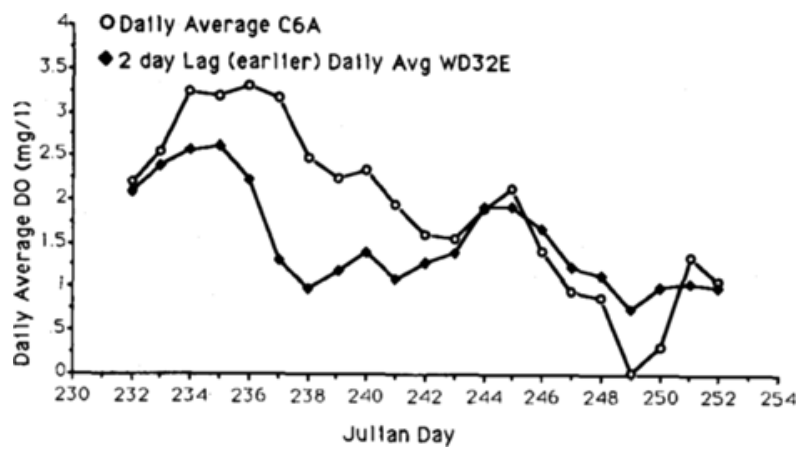

Fig. 6. Comparison of daily near-bottom DO average for station (6.6A (open circle) and a 2-d lagged average for station WD32F. (closed triangle) for the period Julian days 231-252.

of spatial displacement based on near-bottom currents (see above). Mean monthly-averaged daily ranges of DO at WD32E were $0.9 \pm 0.1 \mathrm{mg}^{1}{ }^{1}$ to $1.5 \pm 0.2 \mathrm{mg} \mathrm{l}^{-1}$ (Table 1). Similar calculations for station C6A, which occurs on a broader, more gently sloping shelf, indicate that a parcel of water must be displaced $15 \mathrm{~km}$ to $18 \mathrm{~km}$ to realize a $1 \mathrm{mg} \mathrm{l}^{-1}$ difference in oxygen concentration.

Lack of strong winds (until late September to early October) capable of breaking down the locally strong stratification gradients suggests that the reoxygenation at either station (C6A in midAugust to early September, and WD32E for most of the record) resulted from lateral advection rather than vertical mixing. Chuang and Wiscman (1983) analyzed data collected by Gordon (1982) at the Exxon Offshore Test Site near station C6A. 'They concluded that the near-bottom currents during summer, those that would advect hypoxia, were not strongly driven by local winds. 'This is again consistent with the weak coherence between wind and dissolved oxygen.

\section{Corrfi ation Betwein Sirorter RfCokds}

The spectral and coherence analyses described above utilized the entire 4-mo period of record. Because so much of the record at station C6A was anoxic, a smaller subset of both records was reexamined for correlation. There was only one extended period in each of the two 4-mo DO timeseries when the oxygen concentration was high enough to analyze for correlation in changes between the oxygen concentration at one station and the other. This period was during late August and early September, from Julian day 231 to 252; the DO was above zero at both stations (Fig. 2). The daily average oxygen concentration at station WD32E and the average oxygen concentration at C6A $2 \mathrm{~d}$ later are shown in Fig. 6. There was a significant correlation (adjusted $\mathrm{r}^{2}=0.47, \mathrm{p}=$ 0.0003 ) between $\mathrm{DO}$ changes between stations.
When the oxygen concentration is rising or falling at station WD32E, the oxygen concentration follows a similar pattern $2 \mathrm{~d}$ later at station C6A.

There are at least two explanations for the observed coherence in oxygen concentration between the two stations in this period. First, the distance between stations is $77 \mathrm{~km}$, so the transit time of $2 \mathrm{~d}$ between the two stations could be covered by a surface current velocity of $45 \mathrm{~cm} \mathrm{~s}$, if surface water parcels travelled in an assumed downfield and longshore flow. Chuang and Wiseman (1983) measured westward moving surface currents of this velocity in the region during summer. One explanation of the lagged correlation between the two stations is to assume that, all other factors being equal, similar organic loading to the bottom layer from similar parcels of water, but $2 \mathrm{~d}$ and $77 \mathrm{~km}$ apart, are likely to reach similar equilibrium points for oxygen concentration. A second explanation is that hypoxic waters are formed in the region of WI 32E and transported to C6A. Near-bottom currents measured at $\mathrm{C} 6 \Lambda$, however, indicate speeds predominantly $<10 \mathrm{~cm} \mathrm{~s}^{-1}$, and a longer theoretical transit time $(8 \mathrm{~d})$ than the lag observed in oxygen concentrations. Also, mean bottom currents at C6A for 1990 were not statistically indistinguishable from zero (Wiseman et al. 1992).

\section{Conclusions}

Continuously recording oxygen meters were placed within $1 \mathrm{~m}$ of the seabed in $20-\mathrm{m}$ water depth at two locations on the Louisiana continental shelf. They recorded considerably different oxygen conditions for a 4-mo period from mid-June through mid-October. At station C6A off Terrebonne Bay, bottom waters were severely depleted in dissolved oxygen and often anoxic for most of the record from mid-June through mid-August. Severe hypoxia also persisted for much of the month of September. There were no strong diurnal or diel patterns in the oxygen time-series at C6A. In contrast, at station WD32E, which is $77 \mathrm{~km}$ east of C6A and closer to the birdsfoot delta of the Mississippi River, DO $\leq 2 \mathrm{mg} \mathrm{l}^{-1}$ occurred for only $50 \%$ of the total record, hypoxic events were shorter in duration than at C6A, and there was a strong diurnal pattern in the oxygen time-series. The record of dissolved oxygen was most coherent with the diurnal bottom-water pressure signal, which suggested the importance of tidal advection in the variability of the oxygen record.

Although the oxygen time-series were considerably different from each other, they were consistent with the processes and conditions relevant to the formation and maintenance of hypoxia on the Louisiana shelf (Rabalais et al. 1991). A highly stratified water-column was present during most of 
the periods of record. Wind-induced mixing was insufficient to reaerate the water-column prior to the outbreak of cold air fronts in late September and early October, at which time a relaxation in the stratification also occurred due to thermal cooling. Lack of strong winds capable of breaking down the stratification suggested that reoxygenation (at C6A in late August and at WD32E for most of the record) resulted from lateral advection. The depth gradient is gradual at C6A so that the hypoxic area is much broader in a cross-shelf direction and the oxygen meter was less likely to be impinged by a normoxic water mass during upwelling- or downwelling-favorable conditions. The steeper depth gradient in the Mississippi River Delta Bight and the occurrence of mid-water oxygen minima for several of the mid-month hydrographic surveys indicated that the WD32E oxygen meter was often near the edge of a hypoxic water mass and was periodically exposed to hypoxia.

The data analyses presented here focused on high frequency events. Clearly, the obvious temporal signal on the shelf is the annual recurrence of extended periods of hypoxia in mid-summer. On a broader geographic scale and a longer time period, the ecosystem response of the Louisiana continental shelf to the combined riverine influence of the Mississippi and Atchafalaya river effluents is apparent in usually disjunct zones of bottom-water hypoxia that mirror somewhat, in a downplume direction, the surface salinity field and surface phytoplankton biomass concentrations that result from the major freshwater inputs (Rabalais et al. 1991, 1992). The period during which the two oxygen meters were deployed did not capture the formation of bottom-water hypoxia. On a broader seasonal scale, the oxygen deficit in the bottom waters on the southeastern shelf off 'Terrebonne Bay is significantly correlated with river flow, implying a time-lag of 2 mo from peak flow in April (Justić et al. 1993). Fluxes of organic matter resulting from primary production (which lags peak river flow by $1 \mathrm{mo}$ ) are likely to be high and sufficient to induce hypoxia in a highly stratified water-column (Justić et al. 1993). A similar 2-mo lag of bottom-water oxygen depletion to Atchafalaya River flow was found for the southwestern Louisiana shelf (Pokryfki and Randall 1987).

\section{ACKNOWLFDGMFNTS}

Research funds were provided by the Louisiana Board of Regents, Louisiana Education Quality Support Fund Grant No. I.F.QSF (1987-90)-RD-A-15; United States Minerals Management Service Cooperative Agreement No. 14-35-0001-30470 through the Minerals Management Service/Louisiana Lniversities Marine Consortium University Research Initiative program; National Occanic and Atmospheric Administration, Coastal Ocean Program Office, Nutrient Enhanced Coastal Ocean Productivity
(NECOP) study, NOAA grant no. NA90AA-D-SG691, project numbers MAR24 and MAR31; I ouisiana Sea Grant Program, grant no. NA89AA-D-SG226, project number R/HPX-1-PD; NOAA National Undersea Research Center grant 90-OR-SCLROV-RABAI AIS; and the Texas Institute of Oceanography, Louisiana Univcrsitics Marinc Consortium, Louisiana State University, and Texas A\&M University at Galveston. We thank the many research associates and ships' crews of the $R / V$ Pelican and $R / V$ Acadiana for assistance in the collection of data and samples. We especially thank Lorene Smith and Endeco, Inc. for the calibration and quality assurance of various oxygen measuring equipment. Lorene Smith and Ben Cole assisted in data reduction and analyses. Union Oil Company of California and Shell Offshore, Inc., granted permission for the deployment of instrumentation near their platforms at ST53B and WD32E, respectively. The United States Government is authorized to produce and distribute reprints for governmental purposes.

\section{Literature Cited}

Chlang, W. S. and W. J. Wiseman, JR. 1983. Iow-frequency current variations west of Mississippi River Delta. EOS 64:1021.

CociRANF., J. D. AND F. J. KF.I.I. 1986. Low-frequency circulation on the Texas-Louisiana shelf. Journal of Geophysical Research 91:10,645-10,659.

COOLEY, J. W. AND J. W. TUKEY. 1965. An algorithm for the machine calculation of complex Fourier series. Mathematics of Computation 19:297.

DADDIO, E., W. J. WISFMAX, JR., AND S. P. MuRRAY. 1978. Inertial currents over the inner shelf near $30^{\circ} \mathrm{N}$. Journal of Physical Oceanography 8:728-733.

DAGG, M. J. 1988. Physical and biological responses to the passage of a winter storm in the coastal and inner shelf waters of the northern Gulf of Mexico. Continental Shelf Research 8: $167-178$.

DiMfoo, G. J., L. F. Bosart, And G. W. Findersfin. 1976. An examination of the frequency and mean conditions surrounding frontal incursions into the Gulf of Mexico and Caribbean Sea. Monthly Weather Review 104:709-718.

Diniel, S. P. ANi W. J. Wisfmax, Jr. 1986. Freshwater on the Louisiana shelf. Continental Shelf Research 6:765-784.

Dortch, Q., N. N. Rabalais, R. E. 'TuRNer, AND G. T. Rowk. 1994. Respiration rates and hypoxia on the Iouisiana shelf. Estuaries 17:862-872.

Exifco, InC. 1988. Operations Manual for the Endeco Type 1184 SSM Pulsed Dissolved Oxygen and Temperature Recorder. Endeco, Inc., Marion, Massachusetts.

GoRdow, R. L.. 1982. Coastal ocean current response to storm winds. Journal of Geophysical Research 87:1939-1951.

Justić, D., N. N. Rabalais, R. E. Turner, and W. J. Wiseman, $J_{R}$. 1993. Seasonal coupling between riverborne nutrients, net productivity, and hypoxia. Marine Pollution Bulletin 26:184 189.

LEMING, I. D. AND W. E. STUNT\%. 1984. Zones of coastal hypoxia revealed by satellite scanning have implications for strategic fishing. Nature 310:136-138.

IoIreNy, S. E., M. J. DAGG, AND T. E. WhITledog. 1990. Enhanced primary production at the plume/oceanic interface of the Mississippi River. Continental Shelf Research 10:639-664.

MIIIIMAN, J. D. AND R. H. MFADE. 1983. World-wide delivery of river sediment to the ocean. Journal of Geology 91:1-21.

MoNTGOMfry, R. B. 1938. Circulation in the upper layers of southern North Atlantic deduced with use of isentropic analysis. Papers in Physical Oceanography and Meteorology, 6, Massachusetts Institute of Technology and Woods Hole Oceanographic Institution, Woods Hole, Massachusetts.

Murray, S. P. 1976. Currents and circulation in the coastal waters of Louisiana. Louisiana State Lniversity, Center for Wetland Resources, Coastal Studies Institute, 'Technical Report No. 210. Baton Rouge, Louisiana. 
ParsoNs, T. R., Y. MAITA, AND C. M. Lalli. 1984. A Manual of Chemical and Biological Methods for Seawater Analysis. Pergamon Press, New York.

Pavei A, J. S., J. L. Ross, And M. E. Chiltendex, Jr. 1983. Sharp reductions in abundance of fishes and benthic macroinvertebrates in the Gulf of Mexico off Texas associated with hypoxia. Northeast Gulf Science 6:167-173.

PokRYFKI, L. AND R. E. RANDALL. 1987. Nearshore hypoxia in the bottom water of the northwestern Gulf of Mexico from 1981 to 1984. Marine Environmental. Research 22:75-90.

Rabai ais, N. N., L. E. S.mith, E. B. Overton, ANd A. L. Zoeller. 1993. Influence of hypoxia on the interpretation of effects of petroleum production activities. OCS Study/MMS 93-0022. United States Department of the Interior, Minerals Management Service, Gulf of Mexico OCS Region, New Orleans, Louisiana.

Rabalais, N. N., R. E. Turner, W. J. Wiseman, JR., Aid D. F. BOESCH. 1991. A brief summary of hypoxia on the northern Gulf of Mexico continental shelf: 1985-1988, p. 35-47. In R. V. Tyson and T. H. Pearson (eds.), Modern and Ancient Continental Shelf Anoxia. Geological Society Special Publication No. 58, The Geological Society, London.

Rabaiais, N. N., R. E. Tlrner, anil W. J. Wiseman, JR. 1992. Distribution and characteristics of hypoxia on the Louisiana shelf in 1990 and 1991, p. 15-20. In Nutrient Enhanced Coastal Ocean Productivity. Publication Number TAMU-SG-92-109, Sea Grant Program, Texas A\&M University, Galveston, Texas.

RENALD, M. 1986. Hypoxia in Louisiana coastal waters during 1983: Implications for fisheries. Fishery Bulletin 84:19-26.
Science: Applications International Corporation. 1989. Gulf of Mexico Physical Oceanography Program, Final Report: Year 5. Vol. II, Technical Report. OCS Report/MMS-890068. United States Department of the Interior, Minerals Managment Service, Gulf of Mexico OCS Region, New Orleans, Louisiana.

SKI AR, F. H. AND R. E. TURNer. 1981. Characteristics of phytoplankton production off Barataria Bay in an area influenced by the Mississippi River. Contributions in Marine Science 24:93106.

Ti:rner, R. E. AND R. L. Allfin. 1982. Planktonic respiration rates in the bottom waters of the Mississippi River Delta Bight. Contributions in Marine Science 25:109-120.

Wisemax, W. J., JR., V. J. Bifrmai,, JR., N. N. Rabalais, and R. E. TURier. 1992. Physical structure of the Louisiana shelf hypoxic region, p. 21-26. In Nutrient Enhanced Coastal Ocean Productivity. Publication Number TAMU-SG-92-109, Sea Grant Program, Texas A\&M University, Galveston, Texas.

Wisfiman, W. J., JR., S. P. Murray, J. M. Bave, A.vd M. W. Tubma.v. 1982. Temperature and salinity variability within the Louisiana Bight. Comtributions in Marine Science 25:109-120.

Wiseman, W. J., JR., R. E. Tlrner, F. J. Kfilly, L. J. Rouse, JR., AND R. F. SilAw. 1986. Analysis of biological and chemical associations near a turbid coastal front during winter 1982. Contributions in Marine Science 29:141-151.

Received for consideration, June 7, 1993 Accepted for publication, January 20, 1994 